\title{
Local Radiotherapy Intensification for Locally Advanced Non-small-cell Lung Cancer - A Call to Arms
}

\author{
Noah S. Kalman, ${ }^{1}$ Elisabeth Weiss, ${ }^{1}$ Paul R. Walker, ${ }^{2}$ Julian G. Rosenman ${ }^{3}$
}

\begin{abstract}
Chemoradiotherapy, the standard of care for locally advanced non-small-cell lung cancer (NSCLC), often fails to eradicate all known disease. Despite advances in chemotherapeutic regimens, locally advanced NSCLC remains a difficult disease to treat, and locoregional failure remains common. Improved radiographic detection can identify patients at significant risk of locoregional failure after definitive treatment, and newer methods of escalating locoregional treatment may allow for improvements in locoregional control with acceptable toxicity. This review addresses critical issues in escalating local therapy, focusing on using serial positron emission tomography-computed tomography to select high-risk patients and employing stereotactic radiotherapy to intensify treatment. We further propose a clinical trial concept that incorporates the review's findings.
\end{abstract}

Clinical Lung Cancer, Vol. 19, No. 1, 17-26 @ 2017 Elsevier Inc. All rights reserved.

Keywords: PET-CT, Serial imaging, Stage III lung cancer, Stereotactic body radiotherapy, Therapy escalation

\section{Introduction}

\section{Magnitude of the Problem}

Lung cancer is the second most common cancer in men and women, but it is the most common cause of cancer death in the United States. An estimated 225,000 new cases of lung cancer were diagnosed in $2016 .{ }^{1}$ Approximately $30 \%$ of these patients presented with locally advanced, but still potentially curable, stage III disease. ${ }^{2}$ At most, $25 \%$ of these patients will be cured. ${ }^{3}$ Therefore, up to 40,000 potentially curable patients with stage III non-small-cell lung cancer (NSCLC) will die each year.

\section{What Is Known About the Best Treatment for Stage III NSCLC}

Clinical trials of patients with stage III NSCLC have demonstrated the benefit of chemotherapy and radiation therapy together versus radiation therapy alone $e^{4}$ or chemotherapy alone. ${ }^{5}$ In addition, there is

${ }^{1}$ Department of Radiation Oncology, Virginia Commonwealth University, Richmond, VA

${ }^{2}$ Division of Hematology/Oncology, Department of Internal Medicine, East Carolina University, Greenville, NC

${ }^{3}$ Department of Radiation Oncology, University of North Carolina at Chapel Hill, Chapel Hill, NC

Submitted: Mar 8, 2017; Revised: May 24, 2017; Accepted: May 30, 2017; Epub: Jun 16,2017

Address for correspondence: Noah S. Kalman, MD, MBA, 401 College St, Box 980058, Richmond, VA 23298-0058

E-mail contact: noah.kalman@vcuhealth.org reasonable evidence that giving both modalities at the same time (concurrently) as opposed to one following the other (sequentially) leads to better outcomes. ${ }^{6}$ However, beyond these general principles, little more is known about how to optimize treatment for these patients. Chemotherapeutic regimens and targeted agents that have slowly increased survival in patients with NSCLC with metastatic disease have not increased survival in patients with stage III disease. ${ }^{7}$

${ }^{12}$ Immunotherapy has opened a new treatment avenue in patients who have metastatic disease, with long term responses seen in a small subset of patients ${ }^{13}$; nonetheless, most patients fail treatment. Ongoing studies are evaluating its efficacy in patients with stage III disease, but no results are currently available to support its use. In summary, clinicians have seen little improvement in patient outcomes with stage III NSCLC in the last 10 to 15 years.

\section{Why Do We Fail to Cure Stage III NSCLC? \\ The Problem of Locoregional Control}

Chemoradiotherapy is the standard of care for locoregional control of locally advanced NSCLC, an absolutely necessary step for curing the patient. However, there is evidence that this modality, by itself, is not adequate for this task. For example, in the seminal study RTOG (Radiation Therapy Oncology Group) 06-17, which compared 2 radiation doses (60 Gy and $74 \mathrm{~Gy}$ ), 30\% to $40 \%$ of patients experienced radiographic evidence of locoregional failure at 2 years, suggesting the persistence of locoregional disease despite definitive therapy ${ }^{14}$ (Figure 1). A meta-analysis regarding patterns of 


\section{Radiotherapy Escalation in Stage III NSCLC}

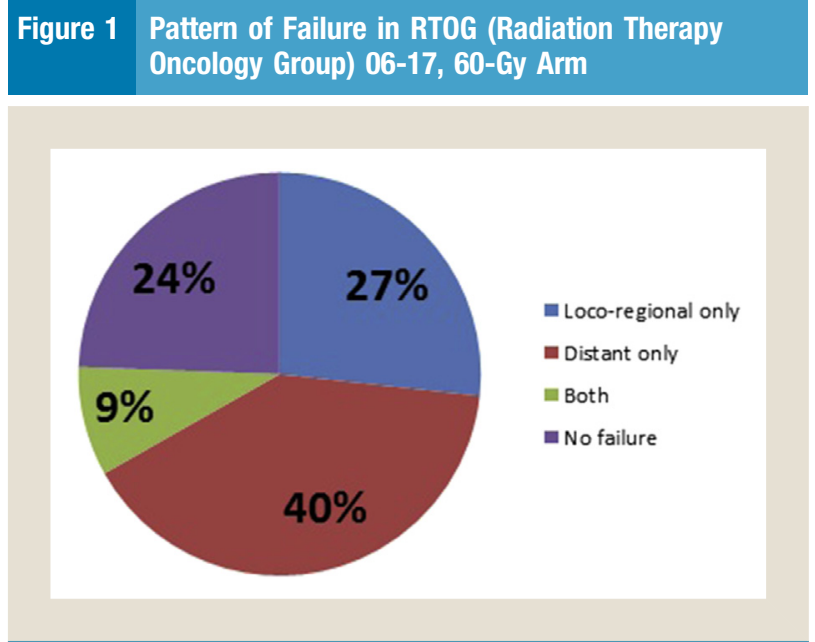

failure reported locoregional failure rates between $31 \%$ and $100 \%$ and mediastinal recurrence rates between $4 \%$ and $56 \% .{ }^{15}$ However, all of these studies relied on radiographic findings to determine the rates of locoregional failure.

Pathologic findings offer more definitive assessments than radiographic ones, and there is accumulating experience in treating patients with stage III operable disease with neoadjuvant chemoradiotherapy followed by surgery. In these patients, a pathologic assessment of response to therapy can be made. Table 1 demonstrates that fewer than half of patients with operable stage III NSCLC achieved pathologic locoregional tumor control following chemoradiotherapy. Higher doses appear to increase control rates, ${ }^{16-21}$ with $60 \mathrm{~Gy}$ leading to a $35 \%$ pathologic complete response rate. ${ }^{20}$

\section{Historical Attempts to Improve Locoregional Tumor Control}

Increasing the radiotherapy dose with conventional fractionation would seem to be a logical way to improve locoregional tumor control. Single-arm studies suggested improvements in survival in locally advanced NSCLC with higher doses, but the large phase III study (RTOG 06-17) failed to show improvement using 74 Gy as compared with $60 \mathrm{~Gy} .{ }^{14}$ Indeed, the higher radiotherapy dose was associated with poorer survival, with possible explanations including increased normal tissue dose (eg, to the heart), worse compliance with radiotherapy planning specifications, and/or poorer treatment tolerability. Locoregional control was also numerically worse in the 74 Gy arm, but this difference was not statistically significant. A recent meta-analysis concluded that dose escalation above $60 \mathrm{~Gy}$ with conventional fractionation did not benefit patients receiving concurrent chemotherapy. ${ }^{22}$

Alternative fractionation regimens have been examined, but direct comparisons to 60 Gy chemoradiotherapy are lacking. ${ }^{23}$ The randomized trials continuous hyperfractionated accelerated radiotherapy (CHART) and CHART weekend-less (CHARTWEL), which used hyperfractionated/accelerated fractionation regimens, showed some improvement in overall survival relative to radiotherapy alone, but with increased toxicity. ${ }^{24,25}$ Interestingly, a multi-institutional study (RTOG 94-10) demonstrated improved local control with twice daily chemoradiotherapy to 69.6 Gy compared with daily chemoradiotherapy to $60 \mathrm{~Gy}$, but survival was higher in the $60 \mathrm{~Gy} \mathrm{arm} .^{26}$ Such accelerated regimens offer a potential benefit over conventionally fractionated dose-escalation regimens by avoiding longer treatment periods and the potential for tumor repopulation.

Surgical resection has also been evaluated in operable patients but has not shown a survival benefit after neoadjuvant chemoradiotherapy in randomized trials. ${ }^{17,19}$ However, neither study reported patterns of failure, so the impact of surgery on locoregional control is unknown.

\section{The Effect of Locoregional Control on Overall Disease Control}

Treatment failures can be divided into those that stem from failure to remove or sterilize locoregional disease and those owing to preexisting occult disease not identified by current staging methods. In the first case, lack of locoregional disease control leads to death from local progression and/or subsequent distant site seeding. In the second case, disease has already disseminated from the primary and/ or regional tumor. In RTOG $06-17$, only $20 \%$ to $30 \%$ of patients remained disease-free at 2 years, ${ }^{14}$ with mixed patterns of failure (Figure 1).

\section{Table 1 Complete Pathologic Downstaging as a Function of Radiation Dose}

\begin{tabular}{|c|c|c|c|c|c|}
\hline Study & No. Patients & Years & Chemoradiation Therapy & Interval to Surgery & $\begin{array}{c}\text { Pathologic CR, } \\
\%\end{array}$ \\
\hline Pisters $^{16}$ & 169 & 1999-2004 & $\begin{array}{l}3 \text { cycles of carboplatin and } \\
\text { paclitaxel. No radiation. }\end{array}$ & $3-8 w k$ & 9 \\
\hline Albain $^{17}$ & 164 & $1994-2001$ & $\begin{array}{l}45 \text { Gy with induction and } \\
\text { concurrent chemotherapy }\end{array}$ & $3-5$ wk & 18 \\
\hline $\mathrm{Kim}^{18}$ & 233 & 1989-2008 & $\begin{array}{l}45 \text { Gy split course with } \\
\text { concurrent chemotherapy }\end{array}$ & Not reported & 22 \\
\hline Eberhardt $^{19}$ & 81 & 2004-2013 & $\begin{array}{l}45 \text { Gy BID with induction and } \\
\text { concurrent chemotherapy }\end{array}$ & 3-9 wk (median 5) & 33 \\
\hline Cerfolio $^{20}$ & 185 & 1998-2008 & $\begin{array}{l}60 \text { Gy with concurrent } \\
\text { chemotherapy }\end{array}$ & Not reported & 35 \\
\hline Edelman $^{21}$ & 40 & $1994-2000$ & $\begin{array}{l}\text { 69.6 Gy BID with concurrent } \\
\text { chemotherapy }\end{array}$ & 3-4 wk $k^{\mathrm{a}}$ & 45 \\
\hline
\end{tabular}

Abbreviation: $\mathrm{BID}=$ twice a day.

aReassessment performed at 3-4 weeks with surgery after reassessment. 
These results and the pathologic outcomes showed in Table 1 suggest that lack of locoregional disease control is a large factor in the poor cure rates currently seen. There are 2 cautions in interpreting these results: first, pathologic complete response rates may underestimate locoregional disease control just as radiographic findings may over- or underestimate true recurrence rates owing to pseudoprogression or occult residual disease; second, better staging could identify occult distant disease as the dominant mode of failure, limiting the number of patients with stage III disease that are curable with improved locoregional disease control. Despite these caveats, locoregional disease control is a prerequisite for cure in these patients.

\section{A Way Forward}

Lack of locoregional control will lead to failure and subsequent death in nearly $100 \%$ of cases. Although attempts to escalate dose using conventional radiation fractionation have been largely unsuccessful, newer methods of escalating locoregional treatment may allow for improvements in locoregional control with acceptable toxicity, especially if patients at significant risk of locoregional failure can be identified.

\section{Critical Issues in Escalating Therapy}

In developing a path forward to improve locoregional treatment for stage III NSCLC, 2 critical issues must be considered: first, patients at significant risk of locoregional failure must be identified; second, effective and safe therapy escalation must be administered. Herein, pertinent data to guide these decisions is reviewed.

\section{Identifying Those at Significant Risk of Locoregional Failure}

Modality of Radiographic Assessment. Positron emission tomography-computed tomography (PET-CT) has emerged as the most effective imaging modality to evaluate pretreatment disease, with a reported sensitivity of $77 \%$ to $81 \%$ and specificity of $79 \%$ to $90 \%$ for detecting mediastinal involvement depending on the criterion used. $^{27}$ It has been both claimed and disputed that pretreatment PET-CT findings are prognostic in patients with lung cancer, ${ }^{28-34}$ with larger and more recent studies failing to demonstrate prognostic value (Table 2). CT-based assessments of pretreatment tumor volume have also demonstrated prognostic value, and pretreatment magnetic resonance imaging can predict response to therapy. ${ }^{35}$ However, prognostic information provided by pretreatment scans does not alter initial therapy, as attempts to escalate initial therapy have lacked benefit and increased toxicity. More important is whether serial peritreatment scans can identify those at significant risk of locoregional failure despite receiving definitive therapy, so that treatment can subsequently be adapted.

Serial PET-CT imaging has demonstrated prognostic value in assessing treatment response that is more robust than the data supporting other radiographic modalities (CT, magnetic resonance imaging). ${ }^{35-37}$ Cerfolio et al and others showed that PET-CT performed after neoadjuvant chemotherapy or chemoradiotherapy predicted pathologic complete response rates. ${ }^{38-40}$ Similarly, PETCT response predicted survival in studies of chemoradiotherapy with or without subsequent surgery ${ }^{32,41-44}$ (Table 3). In these reports, patients with greater declines in tumor PET avidity on posttreatment scans relative to pretreatment scans had improved disease control outcomes. For the minority of patients that meet these PET response thresholds after treatment, further therapy may not be required. However, the majority of patients remain at high risk of locoregional failure, and serial PET-CT assessment can be used to identify these patients that are most appropriate for escalation of locoregional therapy.

Timing of Serial Imaging. Studies involving serial PET-CT imaging vary widely in their timing, but can be grouped into posttreatment and intratreatment categories. ${ }^{45}$ Serial PET-CT roughly 2 weeks following completion of radiation therapy has demonstrated the ability to predict pathologic response and survival in patients receiving chemoradiotherapy for stage III NSCLC ${ }^{38-43}$ (Table 3). With the exception of Ryu et $\mathrm{al},{ }^{40}$ these studies assessed the change in maximum standardized uptake value $\left(\mathrm{SUV}_{\max }\right)$ on serial scans, with decreases between $50 \%$ and $80 \%$ indicating improved prognosis. Repeat PET-CT imaging at longer intervals (2-3 months) following radiotherapy showed similar results. ${ }^{32,44}$ Although discrete cut-offs were examined in these studies, many authors concluded that decrease in $\mathrm{SUV}_{\max }$ can be considered a continuous variable with larger changes in $\mathrm{SUV}_{\max }$ conferring greater benefit in patient response to treatment.

\section{Table 2 Prognostic Value of Pretreatment PET-CT}

\begin{tabular}{|c|c|c|c|c|c|}
\hline Study & Publication Year & No. Patients & Stage & $\begin{array}{l}\text { Definition of } \\
\text { Threshold }\end{array}$ & Prognostic Value \\
\hline Cerfolio $^{28}$ & 2005 & 315 & I-IV & $\mathrm{SUV}_{\max } \geq 10$ & $\begin{array}{l}\text { DFS: yes } \\
\text { OS: yes }\end{array}$ \\
\hline Borst ${ }^{29}$ & 2005 & 51 & $|-|||$ & $\operatorname{SUV}_{\max } \geq 15$ & OS: yes \\
\hline Eschmann $^{30}$ & 2006 & 159 & III & $\operatorname{SUV}_{\text {avg }} \geq 12$ & OS: yes \\
\hline Hoang $^{31}$ & 2008 & 214 & |II-IV & $\operatorname{SUV}_{\max } \geq 11.1$ & OS: no \\
\hline Machtay $^{32}$ & 2013 & 226 & III & $S U V_{\max }$ and SUV peak & OS: no \\
\hline Calais $^{33}$ & 2015 & 39 & $\|-\| \|$ & SUV $\max$ & Local relapse: yes \\
\hline Ohri ${ }^{34}$ & 2015 & 28 & III & $\begin{array}{l}\text { MTV total }>60 \mathrm{cc} \\
\text { MTV lesion }>25 \mathrm{cc}\end{array}$ & $\begin{array}{c}\text { DFS: yes } \\
\text { Lesion recurrence: yes }\end{array}$ \\
\hline
\end{tabular}

Abbreviations: DFS = disease-free survival; max = maximum; MTV = metabolic tumor volume; OS = overall survival; PET-CT = positron emission tomography-computed tomography; SUV $=$ standard uptake value. 
Table 3 Prognostic Value of Posttreatment PET-CT

\begin{tabular}{|c|c|c|c|c|c|c|c|c|}
\hline Study & $\begin{array}{l}\text { Publication } \\
\text { Year }\end{array}$ & $\begin{array}{l}\text { No. } \\
\text { Patients }\end{array}$ & Stage & Interval & Prior Therapy & $\begin{array}{l}\text { Subsequent (Planned) } \\
\text { Therapy }\end{array}$ & Definition of Threshold & Prognostic Value \\
\hline Cerfolio $^{38}$ & 2004 & 56 & $1-|| \mid$ & Within $1 \mathrm{mo}$ & Chemotherapy or chemoradiotherapy & Surgery & $\mathrm{SUV}_{\max }$ decrease $>80 \%$ & pCR: yes \\
\hline Cerfolio ${ }^{39}$ & 2006 & 93 & III & $\mathrm{NR}^{\mathrm{C}}$ & Chemoradiotherapy & Surgery & $\begin{array}{c}\text { SUV }_{\max } \text { decrease }>75 \% \text { (primary) } \\
\text { or }>50 \%(\mathrm{LN})\end{array}$ & pCR: yes \\
\hline Ryu $4^{0}$ & 2002 & 26 & III & 2 wk & $\begin{array}{l}42 \text { Gy in } 1.5 \text { Gy fx BID (10-day break after } \\
21 \text { Gy) with concurrent } 5 \text {-FU, cisplatin, and } \\
\text { vinblastine }\end{array}$ & $\begin{array}{l}\text { Surgery followed by } \\
12-18 \text { Gy with concurrent } \\
\text { chemotherapy }\end{array}$ & SUV mean $>3$ & pCR: yes \\
\hline Eschmann ${ }^{41}$ & 2007 & 70 & |II & 2 wk & $\begin{array}{l}\text { Weekly carboplatin-paclitaxel } \times 4 \mathrm{c} \rightarrow 45 \text { Gy } \\
\text { in } 1.5 \text { Gy fx BID with concurrent weekly } \\
\text { carboplatin-paclitaxel }\end{array}$ & Surgery & $\mathrm{SUV}_{\max }$ decrease $>80 \%$ & OS: yes \\
\hline Pöttgen ${ }^{42}$ & 2006 & 43 & III & $\mathrm{NR}^{\mathrm{a}}$ & $\begin{array}{c}\text { Cisplatin doublet q3wk } \times 3 c \rightarrow 44-45 \\
\text { Gy in } 1.5 \text { Gy fx BID or } 2 \text { Gy qd with concurrent } \\
\text { cisplatin doublet }\end{array}$ & Surgery & SUVmax decrease $>50 \%$ & $\begin{array}{l}\text { OS: no } \\
\text { ECP: yes }\end{array}$ \\
\hline Pöttgen ${ }^{43}$ & 2016 & 124 & III & $N R^{b}$ & Cisplatin-paclitaxel q3wk $\times 3 c$ & $\begin{array}{c}\text { Chemoradiotherapy } 45 \text { Gy in } \\
1.5 \text { Gy fx BID } \\
\text { followed by surgery or radiotherapy } \\
\text { boost }\end{array}$ & $\mathrm{SUV}_{\max }$ decrease $>50 \%$ & $\begin{array}{l}\text { OS: yes } \\
\text { PFS: yes } \\
\text { ECP: yes }\end{array}$ \\
\hline Machtay $^{32}$ & 2013 & 173 & III & 14 wk & $\begin{array}{c}\geq 60 \text { Gy in } 2 \text { Gy fx qd with concurrent platinum } \\
\text { doublet } \pm \text { adjuvant chemotherapy }\end{array}$ & None & SUV $_{\text {peak }}>3.5$ or 5 & $\begin{array}{l}\text { OS (3.5): no } \\
\text { OS (5): yes }\end{array}$ \\
\hline Mac Manus ${ }^{44}$ & 2005 & 88 & I-III & $70 \mathrm{~d}$ & $\begin{array}{c}60 \text { Gy in } 2 \text { Gy fx ad } \pm \text { concurrent } \\
\text { chemotherapy }\end{array}$ & None & CMR & $\begin{array}{l}\text { OS: yes } \\
\text { DM: yes } \\
\text { LRF: yes }\end{array}$ \\
\hline
\end{tabular}

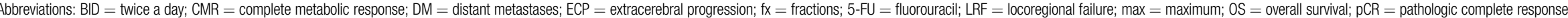
PET-CT = positron emission tomography-computed tomography; PFS = progression-free survival; qd $=$ once a day; q3W = once every 3 weeks.

${ }^{a}$ Average interval of 83 days from start of neoadjuvant therapy to follow up PET-CT, suggesting no interval after completion of therapy.

${ }^{b}$ Average interval of 57 days from the start of neoadjuvant therapy to follow up PET-CT, suggesting a 2-week interval after the start of the final chemotherapy cycle

CTiming of post-neoadjuvant therapy PET-CT not known, but presumed to be within 1 month per prior studies from the same group.

Adapted from van Loon et al. 


\begin{tabular}{|c|c|c|c|c|c|c|c|c|}
\hline Study & $\begin{array}{c}\text { Publication } \\
\text { Year }\end{array}$ & $\begin{array}{c}\text { No. } \\
\text { Patients }\end{array}$ & Stage & $\begin{array}{l}\text { Timing of } \\
\text { PET-CT }\end{array}$ & Therapy & $\begin{array}{c}\text { Subsequent } \\
\text { (Planned) } \\
\text { Therapy }\end{array}$ & $\begin{array}{c}\text { Definition of } \\
\text { Threshold }\end{array}$ & Prognostic Value \\
\hline Toma-Dasu ${ }^{46}$ & 2015 & 27 & III & $\begin{array}{l}\text { Week } 2 \text { of } \\
\text { radiotherapy }\end{array}$ & $\begin{array}{c}\text { Cisplatin- } \\
\text { gemcitabine } \times 3 \mathrm{c} \rightarrow \\
79.2 \text { Gy in } 1.8 \mathrm{~Gy} \mathrm{fx} \\
\text { qd OR cisplatin- } \\
\text { vinorelbine } \times 1 \mathrm{c} \rightarrow \\
45 \mathrm{~Gy} \text { in } 1.5 \mathrm{~Gy} \mathrm{fx} \\
\text { BID then } 2 \mathrm{~Gy} \text { fx qd } \\
\text { up to } 69 \text { Gy with } \\
\text { concurrent cisplatin- } \\
\text { vinorelbine }\end{array}$ & None & $\begin{array}{l}\text { Average change in } \\
\text { SUV per dose } \\
\text { delivered (continuous } \\
\text { variable) }\end{array}$ & OS: yes \\
\hline Usmanij $^{47}$ & 2013 & 28 & III & $\begin{array}{l}\text { Beginning week } 3 \\
\text { of radiotherapy }\end{array}$ & $\begin{array}{c}66 \text { Gy in } 2 \text { Gy fx qd } \\
\text { with concurrent } \\
\text { cisplatin-etoposide } \pm \\
\text { lobectomy }\end{array}$ & None & TLG decrease $>38 \%$ & PFS: yes \\
\hline Yossi $^{48}$ & 2015 & 31 & $\|-\| \|$ & After 30 Gy & $\begin{array}{l}66-70 \text { Gy in } 2 \text { Gy fx } \\
\text { qd with concurrent } \\
\text { platinum doublet }\end{array}$ & None & TLG decrease $>15 \%$ & $\begin{array}{l}\text { OS: yes } \\
\text { PFS: yes }\end{array}$ \\
\hline Huang ${ }^{49}$ & 2011 & 37 & III-IV & After 40 Gy & $\begin{array}{l}40 \text { Gy in } 2 \text { Gy fx qd } \\
\text { with concurrent } \\
\text { cisplatin doublet then } \\
1.4 \text { Gy fx BID up to } \\
62.4-68 \text { Gy }\end{array}$ & $\begin{array}{c}\text { Adjuvant } \\
\text { cisplatin doublet } \\
\text { X 2-4c }\end{array}$ & $\begin{array}{c}\text { SUVmax decrease } \\
\text { MTV }\end{array}$ & $\begin{array}{c}\text { CT response } 4 \text { weeks } \\
\text { post-tx: yes }\end{array}$ \\
\hline Zhang ${ }^{50}$ & 2011 & 46 & III & After 40-50 Gy & $\begin{array}{l}\text { 60-65 Gy in 1.8-2 } \\
\text { Gy fx qd with } \\
\text { concurrent cisplatin } \\
\text { doublet } \pm \text { adjuvant } \\
\text { chemotherapy }\end{array}$ & None & $\begin{array}{l}\text { SUVmax decrease } \\
\quad>50 \%\end{array}$ & OS: yes \\
\hline Kong $^{51}$ & 2007 & 15 & $|-|||$ & After 45 Gy & $\begin{array}{l}60+\text { Gy in } 2+\text { Gy } \\
\text { fx qd } \pm \text { concurrent } \\
\text { and adjuvant } \\
\text { carboplatin-paclitaxel }\end{array}$ & None & CMR & CT response: yes \\
\hline Huang ${ }^{52}$ & 2015 & 53 & III & After 40 Gy & $\begin{array}{l}40 \text { Gy in } 2 \text { Gy fx qd } \\
\text { with concurrent } \\
\text { cisplatin doublet then } \\
1.4 \text { Gy fx BID up to } \\
62.4-76.4 \text { Gy }\end{array}$ & $\begin{array}{l}2-4 c \text { adjuvant } \\
\text { cisplatin doublet }\end{array}$ & $\begin{array}{l}\text { MTV decrease } \\
>29.7 \%\end{array}$ & LRFS: yes \\
\hline
\end{tabular}

Abbreviations: BID = twice a day; fx = fraction; LRFS = local relapse-free survival; MTV = metabolic tumor volume; OS = overall survival; PFS = progression-free survival; qd = once a day; $\mathrm{TLG}=$ total lesion glycolysis.

Adapted from van Loon et al. ${ }^{45}$

Intratreatment serial PET-CT offers the ability to adapt therapy midtreatment, but data supporting this timing is limited to small series. In patients undergoing thoracic radiotherapy or chemoradiotherapy, decreases in overall tumor activity (not $S_{\text {max }}$ ) 2 to 3 weeks into treatment correlated with overall survival and/or progression free survival. $^{46-48}$ Series examining PET-CT changes 4 to 5 weeks into chemoradiotherapy treatment also appeared to stratify responders and nonresponders, ${ }^{49-52}$ but only one study showed an association of PETCT changes with survival, ${ }^{50}$ and these studies differed significantly in their benchmarks to evaluate PET-CT response. Table 4 summarizes these results. The current multi-institutional study RTOG 11-06 uses PET-CT at 5 weeks to identify tumor lesions amenable to dose escalation, with the treatment dose based on retrospective data. ${ }^{53}$ However, this approach has not been definitively proven.

There have been concerns that areas of radiotherapy-induced inflammation, which are fluorodeoxyglucose (FDG)-avid, can limit the diagnostic accuracy of serial PET-CT imaging in the peritreatment period. However, these concerns are not substantiated in published reports. Quantitative assessments of lung parenchyma
PET avidity 3 months after radiotherapy show minor changes from baseline in normal lung tissue relative to large changes from baseline in lung tumors. ${ }^{54}$ In one study, radiotherapy-induced inflammatory lung changes were actually lower on intratreatment PET-CT scans compared with 3-month PET-CT scans. ${ }^{51}$

In light of the data supporting early response assessment after completion of initial therapy, serial scans at roughly 2 weeks posttreatment appear to allow identification of patients appropriate for immediate therapy escalation. This small break limits the degree of tumor repopulation, consistent with timing of surgery in most protocols with neoadjuvant chemoradiotherapy. ${ }^{17,19}$ Tumors often shrink during and immediately following radiotherapy, ${ }^{55}$ so a small break provides the additional benefit of treating a smaller target. Furthermore, the data supporting this approach is more robust than that supporting intratreatment assessment.

Criteria for Determining Likelihood of Residual Disease. Of the studies that evaluated response to therapy with PET-CT early following completion of chemoradiotherapy, a decrease in $\mathrm{SUV}_{\max }$ of 
Table 5 Series of SBRT Following Chemoradiotherapy

\begin{tabular}{|c|c|c|c|c|c|c|c|c|c|}
\hline Study & $\begin{array}{l}\text { Publication } \\
\text { Year }\end{array}$ & $\begin{array}{c}\text { No. } \\
\text { Patients }\end{array}$ & Initial Therapy & $\begin{array}{c}\text { Subsequent Boost } \\
\text { Therapy }\end{array}$ & Target & Timing of Boost & Boost Criteria & $\begin{array}{c}\text { Median } \\
\text { Follow-up, } \\
\text { mo }\end{array}$ & Outcomes \\
\hline Feddock $^{61}$ & 2013 & 35 & $\begin{array}{l}60 \text { Gy chemoradiotherapy } \\
\text { with platinum doublet }\end{array}$ & $\begin{array}{c}10 \text { Gy } \times 2 \mathrm{fx} \text { (peripheral) } \\
\text { or } 6.5 \text { Gy } \times 3 \mathrm{fx} \\
\text { (medial) }\end{array}$ & $\begin{array}{c}\text { Residual disease }+ \\
1 \text {-cm cranio-caudal, } \\
0.5-\mathrm{cm} \text { radial expansion }\end{array}$ & $\begin{array}{l}\text { Median time to } \\
\text { completion of SBRT } 2 \\
\text { mos after initial treatment }\end{array}$ & $\begin{array}{c}\text { Residual disease } \leq 5 \mathrm{~cm} \\
\text { on PET-CT } \sim 1 \mathrm{mo} \text { after } \\
\text { chemoradiotherapy without } \\
\text { nodal or distant disease }\end{array}$ & 13 & $\begin{array}{c}\text { LC } 1 \text { y: } 83 \% \\
\text { Gr } 3 \text { RP: acute } 11 \%, \\
\text { late } 3 \% \\
\text { Gr } 2 \text { + RP: acute } 17 \% \text {, } \\
\text { late 9\% } \\
2 \text { Gr } 5 \text { pulmonary } \\
\text { hemorrhage }^{2}\end{array}$ \\
\hline Karam $^{62}$ & 2013 & 16 & $\begin{array}{l}50.4 \text { Gy } \\
\text { chemoradiotherapy }\end{array}$ & 5 Gy $\times 5 f x$ & $\begin{array}{l}\text { Residual disease on } \\
\mathrm{CT}+0.5 \text {-cm expansion }\end{array}$ & $\begin{array}{l}\text { Median } 20 \mathrm{~d} \text { after initial } \\
\text { treatment }\end{array}$ & $\begin{array}{l}\text { All patients received } \\
\text { boost to primary } \pm \text { LNs }\end{array}$ & 14 & $\begin{array}{l}\text { OS } 1 \text { y: } 78 \% \\
\text { PFS } 1 \text { y: } 42 \% \\
\text { LC 1 y: } 76 \% \\
\text { RC } 1 \text { y: } 79 \% \\
\text { DC } 1 \text { y: } 71 \% \\
\text { Gr } 2 \text { acute RP: } 25 \%\end{array}$ \\
\hline Hepel $^{63}$ & 2016 & 12 & $\begin{array}{c}50.4 \mathrm{~Gy} \\
\text { chemoradiotherapy with } \\
\text { platinum doublet }\end{array}$ & $\begin{array}{l}\text { 8-14 Gy } \times 2 \mathrm{fx}(42 \% \\
\text { also received adjuvant } \\
\text { chemotherapy) }\end{array}$ & $\begin{array}{l}\text { Residual disease + } \\
0.5 \text {-cm expansion }\end{array}$ & 1-4 wk after initial treatment & $\begin{array}{l}\text { Primary tumor }<120 \mathrm{cc} \text {, } \\
\text { nodal volume }<60 \mathrm{cc}\end{array}$ & 15.5 & $\begin{array}{c}\text { LC } 1 \text { y: } 78 \%(60 \% \text { if }<24 \\
\text { Gy; } 100 \% \text { if } \geq 24 \text { Gy) } \\
\text { OS } 1 \text { y: } 67 \% \\
\text { No Gr } 3 \text { RP } \\
1 \text { Gr } 5 \text { toxicity }\end{array}$ \\
\hline Trovo ${ }^{64}$ & 2014 & 17 & $\begin{array}{c}50-60 \text { Gy } \\
\text { chemoradiotherapy }\end{array}$ & 30 Gy in 5-6 fx & $\begin{array}{c}\text { Residual disease + } \\
\text { 0.5-cm expansion }\end{array}$ & $\begin{array}{l}\text { Median } 18 \mathrm{mo} \text { after } \\
\text { initial treatment }\end{array}$ & $\begin{array}{l}\text { In field recurrent or } \\
\text { persistent central tumor } \\
\text { on PET-CT }\end{array}$ & 18 & $\begin{array}{c}\text { LC } 1 \text { y: } 86 \% \\
\text { DM } 1 \text { y: } 47 \% \\
\text { OS 1/2 y: } 59 \% / 29 \% \\
\text { Gr } 3+\text { RP: } 35 \% \\
2 \text { Gr } 5 \text { toxicity }\end{array}$ \\
\hline
\end{tabular}

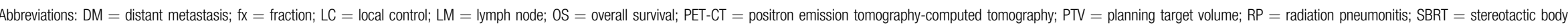
radiation therapy.

10 months after SBRT boost. Both had developed cavitany recurrences involving the hilum, in 1 case, the hilum was included within the high-dose PTV.

BBronchopulmonary hemorrhage 13 months after SBRT boost; patient had received $12 \mathrm{~Gy} \times 2 \mathrm{fx}$. On review, dose to the proximal bronchovascular tree was higher than all other patients.

'One with pneumonitis 4 months after SBRT, one with hemoptysis 2 months after SBRT. 
$>50 \%$ to $80 \%$ was used to predict both residual disease and overall survival. $^{38,39,41-43}$ Recent updated PET-CT guidelines use PET response criteria in solid tumors (PERCIST) criteria to evaluate tumor response to therapy. ${ }^{56}$ Complete metabolic response is defined as "complete resolution of FDG uptake within measurable target lesion so that it is less than mean liver activity and indistinguishable from surrounding background blood-pool levels." In effect, any residual FDG uptake is suspicious for persistent disease. This definition conforms fairly well to thresholds used in surgical series ${ }^{38-40}$ and can be used to identify high-risk patients.

\section{Escalating Locoregional Therapy}

Mode of Escalation. Having identified patients at high risk for locoregional failure following chemoradiotherapy, possible interventions can be considered. Surgery has been a mainstay of therapy for stage III NSCLC for many years. ${ }^{17,19,20,41}$ However, most patients are inoperable, even after initial therapy, owing to comorbidities or tumor location. In a recent nonrandomized study, RTOG 02-29, only two-thirds of operable patients underwent surgery after chemoradiotherapy, with $15 \%$ developing significant postoperative complications. ${ }^{57}$ Therefore, other options are needed.

Stereotactic body radiotherapy (SBRT) has gained prominence in lung cancer owing to its effectiveness in treating early stage lesions. ${ }^{58}$ With SBRT, a higher biologically effective dose (BED) is delivered relative to conventionally fractionated radiotherapy, with an accepted threshold dose of $100 \mathrm{~Gy}$ in lung cancer. ${ }^{59}$ Such high doses delivered in short time periods have the potential to provide better tumor control above the limited effects seen in conventionally fractionated dose escalation regimens for stage III NSCLC. ${ }^{22}$ Several institutions have taken the tools of lung SBRT and applied them to locally advanced disease. ${ }^{60}$ Four prospective studies have examined SBRT to boost residual disease or treat isolated recurrences ${ }^{61-64}$ (Table 5). In these studies, the total delivered BED ranged between 100 and 150 Gy.

In the largest study, Feddock et al delivered a SBRT boost to 35 patients immediately following the completion of chemoradiotherapy to $60 \mathrm{~Gy}$. The boost target was defined by the residual disease seen on PET-CT performed roughly 1 month after completing initial therapy. Patients with residual primary tumors $>$ $5 \mathrm{~cm}$ or residual nodal disease were excluded. The initial boost dose was $20 \mathrm{~Gy}$ in 2 fractions, but after 2 grade 5 toxicities, the dose for central lesions was modified to 19.5 Gy in 3 fractions. ${ }^{61}$ Karam et al delivered a SBRT boost of 20 to 30 Gy in 5 fractions after an initial 50.4 Gy of chemoradiotherapy. Boost treatment started within a month after completion of initial therapy, and the target volume included involved mediastinal lymph nodes. No grade 3 to 5 toxicity was observed in this cohort. ${ }^{62}$ In a recently published doseescalation study, Hepel et al provided a SBRT boost after 50.4 Gy chemoradiotherapy. The SBRT boost, which targeted the residual primary tumor and lymph nodes, was escalated in 4 Gy increments from 16 Gy to 28 Gy in 2 fractions (3 patients per dose level). Interestingly, patients who received 24 or $28 \mathrm{~Gy}$ had $100 \%$ local control at 1 year compared with $60 \%$ in the patients treated to 16 and $20 \mathrm{~Gy}$. One grade 5 toxicity occurred in a patient treated to 24 Gy with high dose delivered to the proximal bronchovascular tree. However, toxicity in the remaining patients was limited. ${ }^{63}$

Other methods of dose escalation that use modestly hypofractionated radiotherapy are under examination (RTOG 11-06), although results are not yet available. Different radiotherapy modalities such as proton therapy and carbon ion therapy have also been explored in treating lung cancer, and may offer improved dosimetry relative to photons, ${ }^{65}$ although their availability is limited. Interventions such as radiofrequency ablation have been tested in early stage lung cancer, but studies comparing radiofrequency ablation with SBRT found SBRT to be superior. ${ }^{66}$

Immunotherapy, now commonly used in the metastatic setting, has been proposed for adjuvant treatment in patients with stage III disease after chemoradiotherapy. ${ }^{67}$ Interestingly, the combination of SBRT and immunotherapy may have a synergistic effect. Multiple reports have shown that SBRT can potentiate the effect of immunotherapy across multiple tumor types, including NSCLC. ${ }^{68}$ Data is limited to patients with metastatic disease, but further investigation may show that combination therapy offers better locoregional and distant disease control than either alone.

Multiple series across different institutions have documented the feasibility of lung SBRT after chemoradiotherapy. SBRT, whether using photons or heavy particles, has been shown to be feasible across patients with varying degrees of comorbidities and appears to be the optimal method to escalate therapy. Further study is required to consider combining radiotherapy and immunotherapy.

\section{Target Definition for SBRT. Primary Versus Lymph Nodes}

There is some debate whether the primary tumor is the only site that requires dose escalation or whether involved lymph nodes are also at significant risk. The lower volume of disease in lymph nodes is more likely to be cleared with lower doses of radiation relative to the larger primary sites. ${ }^{69}$ However, the pattern of recurrence in stage III NSCLC is both local and regional. ${ }^{15}$ Limited series have demonstrated that PET-CT detects residual nodal disease after chemoradiotherapy. ${ }^{39}$ In addition, the study RTOG 02-35 demonstrated that residual PET avidity in lymph nodes independently predicted for locoregional failure. ${ }^{70}$ These results support the treatment of all residual disease, whether it involves the primary tumor or mediastinal lymph nodes.

Correlation of PET Avidity and Residual Tumor

PET-avid areas represent sites with the highest likelihood of harboring residual tumor. However, PET avidity is an imperfect representation of tumor presence, as hypoxic or necrotic tumor volumes may demonstrate little FDG uptake despite the presence of viable cells, and non-tumor-bearing areas can appear PET-avid. ${ }^{71}$ As residual PET avidity is associated with poorer outcomes, 2 current studies utilize FDG uptake to direct boost therapy (RTOG 11-06 and a Dutch study) ${ }^{72}$ for increased dose deposition. Concern for Microscopic Disease at Residual Disease Sites

In delineating targets in stage III NSCLC, radiation oncologists expand the target beyond the gross target volume (GTV) to ensure coverage of microscopic disease extension, with the expansions related to histology and location of disease. However, typically no target expansion is performed in lung SBRT, with the rationale that disease extension is more limited at early stages and that the intermediate radiation dose received by the tissue surrounding the target volume is sufficiently high to eradicate microscopic disease. In patients that have already received full-dose chemoradiotherapy with target expansions to address microscopic disease, expanding the SBRT boost target would be unlikely to increase tumor control. 


\section{Radiotherapy Escalation in Stage III NSCLC}

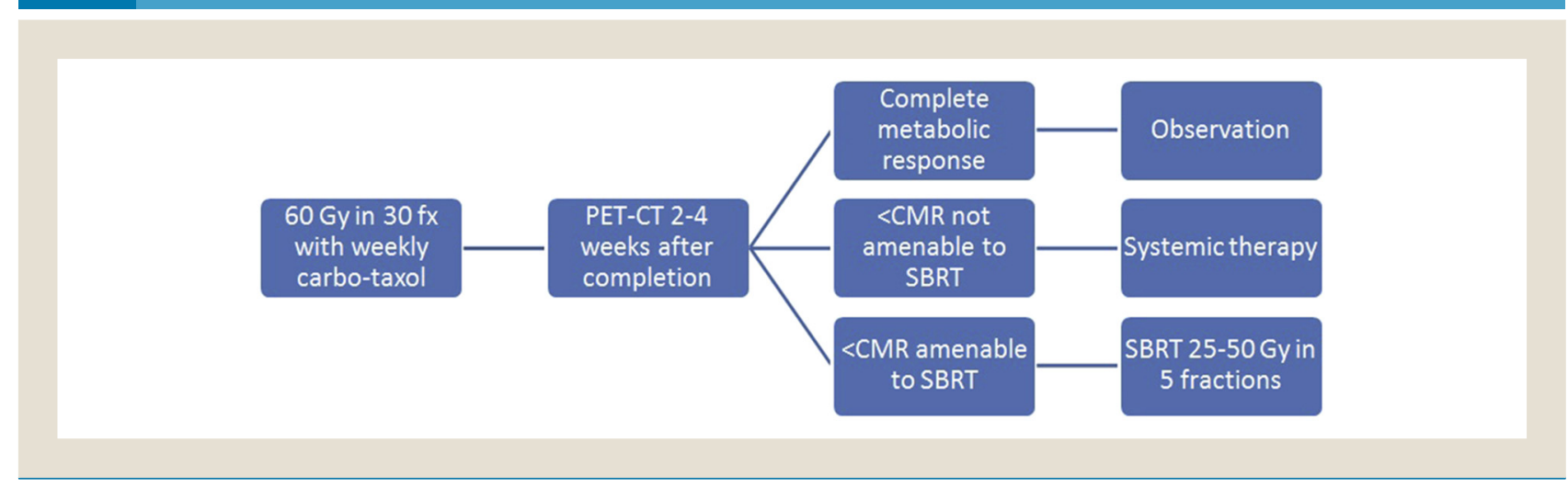

Abbreviations: $\mathrm{CMR}=$ complete metabolic response; $\mathrm{fx}=$ fractions; PET-CT $=$ positron emission tomography-computed tomography; SBRT $=$ stereotactic body radiation therapy.

Therefore, limiting the boost target to the volume of residual PET avidity will likely reduce toxicity without sacrificing disease control.

\section{Normal Tissue Tolerance. Organs at Risk}

Established dose constraints for thoracic radiotherapy exist for both conventionally fractionated radiation and SBRT. Organs at risk include the lung, spinal cord, chest wall, esophagus, heart, great vessels, brachial plexus, and large and small airways. Treating tumors adjacent to large airways with SBRT has generated particular concern, with multiple publications reporting increased toxicity when treating lesions surrounding the proximal bronchovascular tree. ${ }^{59,73-75}$ Indeed, grade 5 toxicities in patients receiving a SBRT boost after chemoradiotherapy were associated with central lesions. ${ }^{61,62}$ RTOG 08-13, a dose-finding study that examined SBRT specifically for early stage lesions abutting the proximal bronchovascular tree and/or mediastinum, reported that treatment was safe and effective, ${ }^{76}$ although grade 5 toxicities occurred. Overall, the study's dose constraints appear to be a reasonable starting point, with BED conversions used to estimate the combined effect of conventionally fractionated radiotherapy and SBRT.

After dose constraints are established, various methods can be employed to help meet these constraints. Active breath hold or respiratory gating can limit the area of irradiated lung tissue if patients can tolerate these measures. Image guidance with cone-beam CT would be mandatory to reduce required treatment margins. ${ }^{77}$ Mediastinal or central targets would likely require that setup priority be given to critical structures to reduce the risk of treatment toxicity.

Boost Dose

The necessary dose to treat early stage lesions is well established at $>100 \mathrm{~Gy} \mathrm{BED},{ }^{59}$ but the effect of combining conventional and hypofractionated radiation is less known, as is the effect of a 4- to 6week treatment break. Most protocols set a target dose, and if treatment plans cannot sufficiently spare normal tissue, those patients are excluded from the study. Another method that has increased in frequency is to set normal tissue constraints and escalate dose to the target until these constraints are reached. Indeed, differential doses could be given to mediastinal and primary tumor sites in a given patient to limit dose to the proximal bronchovascular tree. Because the effect of combining conventionally fractionated radiotherapy with SBRT is not known, a dose-escalation study design has the added benefit of establishing dose thresholds for disease eradication and normal tissue toxicity. Although toxicity will likely be higher in these patients, escalating dose is necessary given the near certainty of death without further treatment.

\section{Clinical Trial Concept}

We propose a clinical trial concept that builds on the ideas discussed in this article (Figure 2). In patients with stage IIIA to B NSCLC, initial treatment would consist of the standard arm of RTOG 06-17, which was radiation with 60 Gy in 30 daily fractions with concurrent weekly chemotherapy carboplatin and paclitaxel. Intensity-modulated radiation therapy planning would be preferred to increase treatment conformality. A baseline PET-CT would be obtained prior to starting chemoradiotherapy, as is commonly done for routine staging. Pathologic confirmation would be required through sampling of an involved lymph node station or primary tumor.

Roughly 2 weeks following the completion of chemoradiotherapy, a repeat PET-CT would be performed. At this point, patients would be separated into 3 groups: (1) patients with complete metabolic response to all sites of disease by PERCIST criteria; (2) patients without complete metabolic response with residual disease not amenable to SBRT; and (3) patients without complete metabolic response but with residual disease amenable to SBRT.

Patients with complete metabolic response would not receive additional therapy. Patients without complete metabolic response and not amenable to SBRT would receive systemic therapy at the treating oncologists' discretion and would be restaged at a later date for consideration of SBRT if disease regressed sufficiently.

Patients with residual disease amenable to SBRT would undergo resimulation and receive SBRT (heavy particle therapy would be allowed if available). Treatment would consist of 5 fractions delivered over 2 weeks with a minimum dose per fraction of 5 Gy marginal dose (cumulative dose $\sim 110$ Gy BED). If normal tissue constraints are met, the dose can be escalated up to 10 Gy per fraction, which would represent 100 Gy BED not including the initial course of chemoradiotherapy.

The primary treatment outcome would be progression-free survival at 24 months. Progression would be defined by PERCIST criteria for progressive disease $(>25 \%$ increase in SUV from 
posttreatment imaging or presence of new FDG-avid lesions). Secondary outcomes would include time to locoregional and distant failure, overall survival, and acute and late treatment toxicity. Criteria for early stopping would be significantly increased development of grade $4 / 5$ toxicity relative to historical series. Because the patients that receive SBRT would represent a higher risk population than an unselected stage III cohort, the benchmark for trial success would be to match the $20 \%$ to $30 \%$ progression-free survival at 24 months seen in RTOG 06-17 in this group.

\section{A Call to Arms}

We challenge the thoracic oncology community to contact the authors to assist with designing a comprehensive protocol and to submit for institutional funding. Stage III lung cancer has stubbornly resisted efforts to improve control rates in the past 10 to 15 years. With new diagnostic and treatment tools, progress can be made in this aggressive but curable disease.

\section{Disclosure}

The authors have stated that they have no conflicts of interest.

\section{References}

1. Siegel RL, Miller KD, Jemal A. Cancer statistics, 2016. CA Cancer J Clin 2016; 66: 7-30.

2. Morgensztern D, Ng SH, Gao F, Govindan R. Trends in stage distribution for patients with non-small cell lung cancer: a National Cancer Database Survey. I Thorac Oncol 2010; 5:29-33.

3. Reck M, Heigener DF, Mok T, Soria J-C, Rabe KF. Management of non-smallcell lung cancer: recent developments. Lancet 2013; 382:709-19.

4. Dillman RO, Herndon J, Seagren SL, Eaton WL Jr, Green MR. Improved surviva in stage III non-small-cell lung cancer: seven-year follow-up of cancer and leukemia group B (CALGB) 8433 trial. J Natl Cancer Inst 1996; 88:1210-5.

5. Kubota K, Furuse K, Kawahara M, et al. Role of radiotherapy in combined modality treatment of locally advanced non-small-cell lung cancer. J Clin Oncol 1994; $12: 1547-52$

6. Aupérin A, Le Péchoux C, Rolland E, et al. Meta-analysis of concomitant versus sequential radiochemotherapy in locally advanced non-small-cell lung cancer. J Clin Oncol 2010; 28:2181-90.

7. Yamamoto N, Nakagawa K, Nishimura Y, et al. Phase III study comparing second- and third-generation regimens with concurrent thoracic radiotherapy in patients with unresectable stage III non-small-cell lung cancer: West Japan Thoracic Oncology Group WJTOG0105. J Clin Oncol 2010; 28 $3739-45$.

8. Senan S, Brade A, Wang LH, et al. PROCLAIM: randomized phase III trial of pemetrexed-cisplatin or etoposide-cisplatin plus thoracic radiation therapy followed by consolidation chemotherapy in locally advanced nonsquamous non-small-cell lung cancer. I Clin Oncol 2016; 34:953-62.

9. Wang L, Wu S, Ou G, et al. Randomized phase II study of concurrent cisplatin/ etoposide or paclitaxel/carboplatin and thoracic radiotherapy in patients with stage III non-small cell lung cancer. Lung Cancer 2012; 77:89-96.

10. Tsujino K, Kurata T, Yamamoto S, et al. Is consolidation chemotherapy after concurrent chemo-radiotherapy beneficial for patients with locally advanced non-smallcell lung cancer? A pooled analysis of the literature. I Thorac Oncol 2013; 8:1181-9.

11. Kelly K, Chansky K, Gaspar LE, et al. Phase III trial of maintenance gefitinib or placebo after concurrent chemoradiotherapy and docetaxel consolidation in inoperable stage III non-small-cell lung cancer: SWOG S0023. J Clin Oncol 2008; 26:2450-6.

12. Komaki R, Allen PK, Wei X, et al. Adding erlotinib to chemoradiation improves overall survival but not progression-free survival in stage III non-small cell lung cancer. Int I Radiat Oncol Biol Phys 2015; 92:317-24.

13. Simone CB 2nd, Burri SH, Heinzerling JH. Novel radiotherapy approaches for lung cancer: combining radiation therapy with targeted and immunotherapies. Transl Lung Cancer Res 2015; 4:545-52.

14. Bradley JD, Paulus R, Komaki R, et al. Standard-dose versus high-dose conformal radiotherapy with concurrent and consolidation carboplatin plus paclitaxel with or without cetuximab for patients with stage IIIA or IIIB non-small-cell lung cancer (RTOG 0617): a randomised, two-by-two factorial phase 3 study. Lancet Oncol 2015; 16:187-99.

15. Nguyen NP, Bishop M, Borok TJ, et al. Pattern of failure following chemoradiation for locally advanced non-small cell lung cancer: potential role for stereotactic body radiotherapy. Anticancer Res 2010; 30:953-61.

16. Pisters KM, Vallieres E, Crowley JJ, et al. Surgery with or without preoperative paclitaxel and carboplatin in early-stage non-small-cell lung cancer: Southwest
Oncology Group Trial S9900, an intergroup, randomized, phase III trial. J Clin Oncol 2010; 28:1843-9.

17. Albain KS, Swann RS, Rusch VW, et al. Radiotherapy plus chemotherapy with or without surgical resection for stage III non-small-cell lung cancer: a phase III randomised controlled trial. Lancet 2009; 374:379-86.

18. Kim AW, Liptay MJ, Bonomi P, et al. Neoadjuvant chemoradiation for clinically advanced non-small cell lung cancer: an analysis of 233 patients. Ann Thorac Surg 2011; 92:233-41 [discussion: 241-3].

19. Eberhardt WE, Pottgen C, Gauler TC, et al. Phase III study of surgery versus definitive concurrent chemoradiotherapy boost in patients with resectable stage IIIA(N2) and selected IIIB non-small-cell lung cancer after induction chemotherapy and concurrent chemoradiotherapy (ESPATUE). J Clin Oncol 2015; 33: 4194-201.

20. Cerfolio RJ, Bryant AS, Jones VL, Cerfolio RM. Pulmonary resection after concurrent chemotherapy and high dose (60Gy) radiation for non-small cell lung cancer is safe and may provide increased survival. Eur I Cardiothorac Surg 2009; 35: 718-23 [discussion: 723].

21. Edelman MJ, Suntharalingam M, Burrows W, et al. Phase I/II trial of hyperfractionated radiation and chemotherapy followed by surgery in stage III lung cancer. Ann Thorac Surg 2008; 86:903-10.

22. Ramroth J, Cutter DJ, Darby SC, et al. Dose and fractionation in radiation therapy of curative intent for non-small cell lung cancer: meta-analysis of randomized trials. Int J Radiat Oncol Biol Phys 2016; 96:736-47.

23. Kelsey CR, Das S, Gu L, Dunphy FR 3rd, Ready NE, Marks LB. Phase 1 dose escalation study of accelerated radiation therapy with concurrent chemotherapy for locally advanced lung cancer. Int I Radiat Oncol Biol Phys 2015; 93:997-1004.

24. Baumann M, Herrmann T, Koch R, et al. Final results of the randomized phase III CHARTWEL-trial (ARO 97-1) comparing hyperfractionated-accelerated versus conventionally fractionated radiotherapy in non-small cell lung cancer (NSCLC). Radiother Oncol 2011; 100:76-85.

25. Saunders M, Dische S, Barrett A, Harvey A, Griffiths G, Palmar M. Continuous, hyperfractionated, accelerated radiotherapy (CHART) versus conventional radiotherapy in non-small cell lung cancer: mature data from the randomised multicentre trial. CHART Steering committee. Radiother Oncol 1999; 52:137-48.

26. Curran WJ Jr, Paulus R, Langer CJ, et al. Sequential vs. concurrent chemoradiation for stage III non-small cell lung cancer: randomized phase III trial RTOG 9410. J Natl Cancer Inst 2011; 103:1452-60.

27. Schmidt-Hansen M, Baldwin DR, Hasler E, Zamora J, Abraira V, Roque IFM PET-CT for assessing mediastinal lymph node involvement in patients with suspected resectable non-small cell lung cancer. Cochrane Database Syst Rev 2014: CD009519.

28. Cerfolio RJ, Bryant AS, Ohja B, Bartolucci AA. The maximum standardized uptake values on positron emission tomography of a non-small cell lung cancer predict stage, recurrence, and survival. J Thorac Cardiovasc Surg 2005; 130:151-9.

29. Borst GR, Belderbos JSA, Boellaard R, et al. Standardised FDG uptake: a prognostic factor for inoperable non-small cell lung cancer. Eur J Cancer 2005; 41: 1533-41.

30. Eschmann SM, Friedel G, Paulsen F, et al. Is standardised (18)F-FDG uptake value an outcome predictor in patients with stage III non-small cell lung cancer? Eur J Nucl Med Mol Imaging 2006; 33:263-9.

31. Hoang JK, Hoagland LF, Coleman RE, Coan AD, Herndon JE 2nd, Patz EF Jr. Prognostic value of fluorine-18 fluorodeoxyglucose positron emission tomography imaging in patients with advanced-stage non-small-cell lung carcinoma. J Clin Oncol 2008; 26:1459-64.

32. Machtay M, Duan F, Siegel BA, et al. Prediction of survival by [18F]fluorodeoxyglucose positron emission tomography in patients with locally advanced non-small-cell lung cancer undergoing definitive chemoradiation therapy: results of the ACRIN 6668/RTOG 0235 trial. I Clin Oncol 2013; 31:3823-30.

33. Calais J, Thureau S, Dubray B, et al. Areas of high 18F-FDG uptake on preradiotherapy PET/CT identify preferential sites of local relapse after chemoradiotherapy for non-small cell lung cancer. J Nucl Med 2015; 56:196-203.

34. Ohri N, Piperdi B, Garg MK, et al. Pre-treatment FDG-PET predicts the site of in-field progression following concurrent chemoradiotherapy for stage III nonsmall cell lung cancer. Lung Cancer 2015; 87:23-7.

35. Nishino M, Hatabu H, Johnson BE, McLoud TC. State of the art: response assessment in lung cancer in the era of genomic medicine. Radiology 2014; 271:6-27.

36. Coroller TP, Grossmann P, Hou Y, et al. CT-based radiomic signature predicts distant metastasis in lung adenocarcinoma. Radiother Oncol 2015; 114:345-50.

37. Weiss E, Ford JC, Olsen KM, et al. Apparent diffusion coefficient (ADC) change on repeated diffusion-weighted magnetic resonance imaging during radiochemotherapy for non-small cell lung cancer: a pilot study. Lung Cancer 2016; 96: 113-9.

38. Cerfolio RJ, Bryant AS, Winokur TS, Ohja B, Bartolucci AA. Repeat FDG-PET after neoadjuvant therapy is a predictor of pathologic response in patients with non-small cell lung cancer. Ann Thorac Surg 2004; 78:1903-9 [discussion: 1909].

39. Cerfolio RJ, Bryant AS, Ojha B. Restaging patients with N2 (stage IIIa) non-small cell lung cancer after neoadjuvant chemoradiotherapy: a prospective study. J Thorac Cardiovasc Surg 2006; 131:1229-35.

40. Ryu JS, Choi NC, Fischman AJ, Lynch TJ, Mathisen DJ. FDG-PET in staging and restaging non-small cell lung cancer after neoadjuvant chemoradiotherapy: correlation with histopathology. Lung Cancer 2002; 35:179-87.

41. Eschmann SM, Friedel G, Paulsen F, et al. 18F-FDG PET for assessment of therapy response and preoperative re-evaluation after neoadjuvant radiochemotherapy in stage III non-small cell lung cancer. Eur J Nucl Med Mol Imaging 2007; 34:463-71. 


\section{Radiotherapy Escalation in Stage III NSCLC}

42. Pottgen C, Levegrun S, Theegarten D, et al. Value of 18F-fluoro-2-deoxy-Dglucose-positron emission tomography/computed tomography in non-small-cell lung cancer for prediction of pathologic response and times to relapse after neoadjuvant chemoradiotherapy. Clin Cancer Res 2006; 12:97-106.

43. Pottgen C, Gauler T, Bellendorf A, et al. Standardized uptake decrease on [18F]. fluorodeoxyglucose positron emission tomography after neoadjuvant chemotherapy is a prognostic classifier for long-term outcome after multimodality treatment: secondary analysis of a randomized trial for resectable stage IIIA/B nonsmall-cell lung cancer. J Clin Oncol 2016; 34:2526-33.

44. Mac Manus MP, Hicks RJ, Matthews JP, Wirth A, Rischin D, Ball DL. Metabolic (FDG-PET) response after radical radiotherapy/chemoradiotherapy for non-smal cell lung cancer correlates with patterns of failure. Lung Cancer 2005; 49:95-108.

45. van Loon J, van Baardwijk A, Boersma L, Ollers M, Lambin P, De Ruysscher D. Therapeutic implications of molecular imaging with PET in the combined modality treatment of lung cancer. Cancer Treat Rev 2011; 37:331-43.

46. Toma-Dasu I, Uhrdin J, Lazzeroni M, et al. Evaluating tumor response of nonsmall cell lung cancer patients with (1)(8)F-fludeoxyglucose positron emission tomography: potential for treatment individualization. Int J Radiat Oncol Biol Phys 2015; 91:376-84.

47. Usmanij EA, de Geus-Oei LF, Troost EG, et al. 18F-FDG PET early response evaluation of locally advanced non-small cell lung cancer treated with concomitant chemoradiotherapy. J Nucl Med 2013; 54:1528-34.

48. Yossi S, Krhili S, Muratet JP, Septans AL, Campion L, Denis F. Early assessment of metabolic response by 18F-FDG PET during concomitant radiochemotherapy of non-small cell lung carcinoma is associated with survival: a retrospective singlecenter study. Clin Nucl Med 2015; 40:e215-21.

49. Huang W, Zhou T, Ma L, et al. Standard uptake value and metabolic tumor volume of (1)(8)F-FDG PET/CT predict short-term outcome early in the course of chemoradiotherapy in advanced non-small cell lung cancer. Eur J Nucl Med Mol Imaging 2011; 38:1628-35.

50. Zhang HQ, Yu JM, Meng X, Yue JB, Feng R, Ma L. Prognostic value of serial [18F]fluorodeoxyglucose PET-CT uptake in stage III patients with non-smal cell lung cancer treated by concurrent chemoradiotherapy. Eur J Radiol 2011; 77:92-6.

51. Kong FM, Frey KA, Quint LE, et al. A pilot study of [18F]fluorodeoxyglucose positron emission tomography scans during and after radiation-based therapy in patients with non small-cell lung cancer. J Clin Oncol 2007; 25:3116-23.

52. Huang W, Liu B, Fan M, et al. The early predictive value of a decrease of metabolic tumor volume in repeated (18)F-FDG PET/CT for recurrence of locally advanced non-small cell lung cancer with concurrent radiochemotherapy. Eur J Radiol 2015; 84:482-8.

53. Kong FM, Ten Haken RK, Schipper MJ, et al. High-dose radiation improved local tumor control and overall survival in patients with inoperable/unresectable nonsmall-cell lung cancer: long-term results of a radiation dose escalation study. Int I Radiat Oncol Biol Phys 2005; 63:324-33.

54. McCurdy MR, Castillo R, Martinez J, et al. [18F]-FDG uptake dose-response correlates with radiation pneumonitis in lung cancer patients. Radiother Oncol $2012 ; 104: 52-7$

55. Hugo GD, Weiss E, Badawi A, Orton M. Localization accuracy of the clinical target volume during image-guided radiotherapy of lung cancer. Int J Radiat Oncol Biol Phys 2011; 81:560-7.

56. Wahl RL, Jacene H, Kasamon Y, Lodge MA. From RECIST to PERCIST: evolving Considerations for PET response criteria in solid tumors. I Nucl Med 2009; 50(Suppl 1):122S-50S.

57. Suntharalingam M, Paulus R, Edelman MJ, et al. Radiation Therapy Oncology Group protocol 02-29: a phase II trial of neoadjuvant therapy with concurrent chemotherapy and full-dose radiation therapy followed by surgical resection and consolidative therapy for locally advanced non-small cell carcinoma of the lung. Int J Radiat Oncol Biol Phys 2012; 84:456-63.

58. Timmerman R, Paulus R, Galvin J, et al. Stereotactic body radiation therapy for inoperable early stage lung cancer. JAMA 2010; 303:1070-6.
59. Senthi S, Haasbeek CJ, Slotman BJ, Senan S. Outcomes of stereotactic ablative radiotherapy for central lung tumours: a systematic review. Radiother Oncol 2013; 106:276-82.

60. De Ruysscher D, Faivre-Finn C, Le Pechoux C, Peeters S, Belderbos J. High-dose re-irradiation following radical radiotherapy for non-small-cell lung cancer. Lancet Oncol 2014; 15:e620-4.

61. Feddock J, Arnold SM, Shelton BJ, et al. Stereotactic body radiation therapy can be used safely to boost residual disease in locally advanced non-small cell lung cancer: a prospective study. Int J Radiat Oncol Biol Phys 2013; 85:1325-31.

62. Karam SD, Horne ZD, Hong RL, McRae D, Duhamel D, Nasr NM. Dose escalation with stereotactic body radiation therapy boost for locally advanced non small cell lung cancer. Radiat Oncol 2013; 8:179.

63. Hepel JT, Leonard KL, Safran H, et al. Stereotactic body radiation therapy boost after concurrent chemoradiation for locally advanced non-small cell lung cancer: a phase 1 dose escalation study. Int J Radiat Oncol Biol Phys 2016; 96:1021-7.

64. Trovo M, Minatel E, Durofil E, et al. Stereotactic body radiation therapy for reirradiation of persistent or recurrent non-small cell lung cancer. Int $J$ Radiat Oncol Biol Phys 2014; 88:1114-9.

65. Wink KC, Roelofs E, Solberg T, et al. Particle therapy for non-small cell lung tumors: where do we stand? A systematic review of the literature. Front Oncol 2014; 4:292.

66. Bi N, Shedden K, Zheng X, Kong F-M. Comparison of the effectiveness of radiofrequency ablation with stereotactic body radiation therapy in inoperable stage I non-small cell lung cancer: a systemic review and pooled analysis. Int J Radiat Oncol Biol Phys 2016; 95:1378-90.

67. Durm GA, Kio EA, Fisher WB, et al. Phase II trial of consolidation pembrolizumab following concurrent chemoradiation in patients (pts) with unresectable or inoperable stage III non-small cell lung cancer (NSCLC): initial safety data from HCRN LUN 14-179. J Clin Oncol 2016; 34(suppl) (abstract e20025).

68. Schoenhals JE, Seyedin SN, Tang C, et al. Preclinical rationale and clinical considerations for radiotherapy plus immunotherapy: going beyond local control. Cancer I 2016; 22:130-7.

69. Kong FM, Zhao J, Wang J, Faivre-Finn C. Radiation dose effect in locally advanced non-small cell lung cancer. $J$ Thorac Dis 2014; 6:336-47.

70. Markovina S, Duan F, Snyder BS, Siegel BA, Machtay M, Bradley JD. Regional lymph node uptake of [(18)F]fluorodeoxyglucose after definitive chemoradiation therapy predicts local-regional failure of locally advanced non-small cell lung cancer: results of ACRIN 6668/RTOG 0235. Int J Radiat Oncol Biol Phys 2015; 93:597-605.

71. Christensen JD, Colby TV, Patz EF Jr. Correlation of [18F]-2-fluoro-deoxy-Dglucose positron emission tomography standard uptake values with the cellular composition of stage I nonsmall cell lung cancer. Cancer 2010; 116:4095-102.

72. van Elmpt W, De Ruysscher D, van der Salm A, et al. The PET-boost randomised phase II dose-escalation trial in non-small cell lung cancer. Radiother Oncol 2012; 104:67-71.

73. Timmerman R, McGarry R, Yiannoutsos C, et al. Excessive toxicity when treating central tumors in a phase II study of stereotactic body radiation therapy for medically inoperable early-stage lung cancer. J Clin Oncol 2006; 24:4833-9.

74. Mangona VS, Aneese AM, Marina O, et al. Toxicity after central versus peripheral lung stereotactic body radiation therapy: a propensity score matched-pair analysis. Int J Radiat Oncol Biol Phys 2015; 91:124-32.

75. Lindberg K, Bergström P, Brustugun OT, et al. The Nordic HILUS trial - first report of a phase II trial of SBRT of centrally located lung tumors. World Conference on Lung Cancer 2016; 12:S340, (abstract OA24.05).

76. Bezjak A, Paulus R, Gaspar LE, et al. Efficacy and toxicity analysis of NRG Oncology/RTOG 0813 trial of stereotactic body radiation therapy (SBRT) for centrally located non-small cell lung cancer (NSCLC). Int J Radiat Oncol Biol Phys 2016; 96:S8.

77. Grills IS, Hugo G, Kestin LL, et al. Image-guided radiotherapy via daily online cone-beam CT substantially reduces margin requirements for stereotactic lung radiotherapy. Int J Radiat Oncol Biol Phys 2008; 70:1045-56. 